\title{
Protoplast isolation and plant regeneration in two cultivated coriander varieties, Co-1 and RS
}

\author{
MuZamil Ali, Abdul MujiB *, Nadia Zafar, Dipti Tonk \\ Jamia Hamdard University, New Delhi, India
}

\begin{abstract}
An efficient and reproducible protocol for plant regeneration from protoplasts has been developed in two Coriandrum sativum varieties - Co-1 and Rajendraswathi (RS). The RS coriander is rich in oil and shows resistance to diseases whereas Co-1 is known for better yield. In the present study, protoplast isolation - the first step of fusion was undertaken in cotyledon-derived embryogenic cell suspensions by using enzymatic solutions of different concentrations. Digestion with $2 \%$ cellulase Onozuka R-10, $1 \%$ pectinase and $0.2 \%$ macerozyme R-10 showed the maximum yield of protoplasts $\left(4.60 \times 10^{6} / \mathrm{g}\right.$ of callus) when mannitol was added as the osmoticum. The cell division and plating efficiency, however, varied with the different levels of plant growth regulators (PGRs) used. In a liquid medium amended with $0.2 \mathrm{mg} / 1 \mathrm{\alpha}$-naphthalene acetic acid (NAA) and $0.2 \mathrm{mg} / 1$ 6-benzyladenine (BA), protoplasts showed a higher plating efficiency (6.2\% in Co-1 and 5.4\% in RS) compared to other PGR treatments. On a 2,4-dichlorophenoxy acetic acid (2,4-D)-supplemented medium, cells divided fast, produced micro-colonies, and formed the callus on which a heterogeneous mixture of somatic embryos was produced in both the varieties tested. The maximum number of somatic embryos was produced (47/callus mass) in a medium to which $1 \mathrm{mg} / 12$,4-D was added. On a BA and gibberellic acid $\left(\mathrm{GA}_{3}\right)$-supplemented medium,somatic embryos germinated into plantlets, and the maximum germination frequency (81\%)was noted in a medium to which $1 \mathrm{mg} / 1 \mathrm{BA}$ and $0.5 \mathrm{mg} / 1 \mathrm{GA}$ was added. A successful somatic embryo-mediated plant regeneration was achieved from protoplasts in both coriander varieties, and the regenerated plants were morphologically similar to mother plants. The whole process of "protoplast to plant recovery”, enzymatic mixtures, osmotic condition, and role of PGRs are discussed in this article.
\end{abstract}

Key words: Coriandrum sativum, Co-1, RS, protoplasts, enzymes mixtures, cellulase Onozuka R-10, pectinase, macerozyme R-10, callus, somatic embryos

\author{
Abbreviations \\ PGR - plant growth regulator \\ 2,4-D - 2,4-dichlorophenoxyacetic acid \\ BA - 6-benzyladenine
}

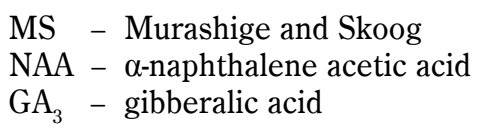

MS - Murashige and Skoog

$\mathrm{GA}_{3}$ - gibberalic acid

\section{Introduction}

Coriandrum sativum L. is a perennial herb from the Apiaceae family. The plant is cultivated both as a spice and as a medicinal plant. The seeds and green parts of the plant are used as flavoring agents because they contain essential oils. $C$. sativum has important medicinal applications that have antidiabetic (Eidi et al., 2009), antibacterial (Duarte et al., 2012), antifungal (Silva et al., 2011), hepatoprotective (Samojlik et al., 2010), and antioxidant activities (Darughe et al., 2012). Coriander is susceptible to several bacterial and fungal pathogens su- ch as Pseudomonas syringae and Fusarium oxysporum (Singh, 2006). In a conventional breeding program, the introduction of new traits is restricted due to reproductive barriers and, furthermore, is hindered by the genetic make-up of populations (Gosal et al., 2010). To address these limitations, a protoplast-based somatic hybridization approach could be used to efficiently overcome sexual incompatibility. In addition, somatic hybrydization enables direct transfer of nuclear and cytoplasmic genomic matters into recipient plant cells (Grosser and Gmitter-Jr, 2011). Other problems associated with sexual re-

\footnotetext{
*Corresponding author: Jamia Hamdard University, M.B. Road, 110062 New Delhi, India; e-mail: amujib3@yahoo.co.in
} 
production are albinism, hybrid vigor, and sterility, which frequently occur during the development of interspecific hybrids (Eeckhaut et al., 2006). Embryogenic cultures/somatic embryos can play an important alternative role in molecular breeding (Singh and Chaturvedi, 2013). Moreover, the plastic nature of differentiated plant cells ensures dedifferentiation and multiple functions during developmental programming (Ondrej et al., 2009). Davey and coworkers (2005) observed that the process of dedifferentiation is a developmental change (under in vitro conditions), which makes progenitor cell sources for plant regeneration. Protoplasts obtain pluripotency, which is an ability to dedifferentiate into other cell types, after the removal of the cell wall land demonstrate chromatin remodeling and transcriptional changes (Xiao et al., 2012). However, Faraco and coworkers (2011) reported that the pluripotent protoplast does not necessarily exhibit plant regeneration because it primarily depends on the source of protoplasts. In somatic hybridization, the development of protoplast is a key step, and it can be obtained from a variety of differentiated young and non-stressed tissues/cells from, for example, leaf mesophyll and roots that can divide and produce cell colonies and then grow into plants (Horii and Marubashi, 2005; Eeckhaut and Van-Huylenbroeck, 2011). Protoplasts have several advantages in investigating plant cell lines, differentiation, dedifferentiation, stem-ness, and pluripotency (Grafi, 2004). Protoplasts are a preferred recipient target source for genetic manipulation in the uptake of foreign DNA, including organelles; moreover, they are used for developing genetic diversity by facilitating somatic hybridization (Davey et al., 2005). There are successful reports on the isolation of viable protoplasts and plant regeneration from diverse tissue sources such as hypocotyls, leaf mesophyll cells, cotyledons, and embryogenic cell suspensions (Kim et al., 2003; Yang et al., 2007). The embryogenic cell suspension has been shown to be very responsive and an efficient source of regenerative protoplasts (Jalil et al., 2003), thereby producing dividing cells at a reasonable rate (Shrestha et al., 2007). Grzebelus and coworkers (2012) described an efficient protoplast isolation and plant regeneration method from leaf and hypocotyl explants by using a 1\% cellulase Onozuka R-10 and $0.1 \%$ pectolyase $\mathrm{Y} 23$ digestive enzyme mixture in carrot - a close relative of the coriander and a member of the Apiaceae family. Further, a successful plant regeneration was obtained from isolated protoplasts in other cultivated and wild species of Daucas wherein the incidence of somatic embryogenesis was first reported (Mackawska et al., 2014). The hypocotyl-derived embryogenic callus was recently used for protoplast isolation in a local variety of coriander (Mujib et al., 2014). A similar use of embryogenic callus or embryos has proved to be essential in obtaining protoplasts prior to somatic hybridization (Prange et al., 2010). The technique of protoplast isolation, culture, and plant regeneration is, however, seemingly complex and influenced by a variety of factors such as enzymatic mixtures, the culture medium, osmoticum, the nitrogen source, and the culture technique or the protocol (Davey et al., 2005). Therefore, it is necessary to study the factors that influence the protoplast-isolation technique to be used in various areas of biotechnology. A number of researchers (Pongchawee et al., 2006; Rizkalla et al., 2007) are of the view that each plant has its own requirement of specific optimal conditions for protoplast isolation and regeneration. Beside its application on somatic hybrids, the conditions of an in vitro culture can cause a physiological stress in cultivated protoplasts, produce genetic alterations such as chromosomal rearrangements and polyploidization, often termed protoclonal variation (Larkin and Scowcroft, 1981). Interestingly, some of the changes are potentially beneficial for improving crops (Gao et al., 2009).

The two coriander varieties under investigation have some unique traits. RS is a medium-sized, aromatic coriander variety that is rich inessential oils compared to Co-1. Moreover, it is resistant to stem gall and moderately resistant to wilt, gives an estimated yield of 13 quintal per hectare, and, therefore, is beneficial to commercial growers (Malhotra and Vashishtha, 2008; Farooq et al., 2017). On the otherhand, Co-1 is a dwarf high-yield variety, showing more globular seeds (Ciju, 2015). Therefore, it is essential to establish a coriander plant with the combined best agronomic traits of the two varieties.

In the present investigation, the primary objective was to establish a protoplast-isolation method for the Co-1 and RS coriander varieties that could be used in future somatic hybridization programs. In addition, the current study undertook to evaluate the effect of enzymatic mixture combinations, the use of plant growth regulators (PGRs) in isolation, and the stages of development in plant regeneration. Furthermore, we aimed to 
investigate and describe the somatic embryogenesis mode of regeneration.

\section{Materials and methods}

\section{Seed germination and culture conditions}

Coriander seeds were obtained from the National Research Centre for Seed Spices, Ajmer, Rajasthan, India. These seeds were disinfected with $0.2 \%(\mathrm{w} / \mathrm{v}) \mathrm{HgCl}_{2}$ for 2 minutes, rinsed 3-4 times with distilled water, and then placed on a half-strength (1/2) MS (Murashige and Skoog, 1962) medium without PGRs for germination. In addition, the medium contained $30 \mathrm{~g} / 1$ sugar and $0.8 \mathrm{~g} / \mathrm{l}$ agar. The medium $\mathrm{pH}$ was adjusted to 5.6 by using $1 \mathrm{~N} \mathrm{NaOH}$ and $1 \mathrm{~N} \mathrm{HCl}$, the media were sterilized in an autoclave at $121^{\circ} \mathrm{C}$ for 15 minutes. All reagents were prepared by using Milli-Q water produced by a Milli-Q system (Billerica, MA, USA). The cultures were incubated at $25 \pm 2{ }^{\circ} \mathrm{C}$ under a 16 -hour photoperiod that was provided by coolwhite fluorescent lamps (100 $\left.\mathrm{mol} \mathrm{m}^{-2} \mathrm{~s}^{-1} \mathrm{PFD}\right)$.

\section{Embryogenic callus induction and somatic embryogenesis}

The cotyledon explants from in vitrogerminated seedlings were cultured on 2,4-dichlorophenoxy acetic acid (2,4-D; 0.5, 1, and $2 \mathrm{mg} / \mathrm{l})$ and BA (0.2 mg/l) - amended MS medium for callus formation. Within a few days, the callus was formed from the cut ends of explants and grew profusely. After 4 weeks of culture, the callus was transferred to various concentrations of 2,4-D (0.5-2 mg/l) for further growth. Immediately after transfer, the callus turned into granular embryogenic tissues that then began to differentiate into a number of embryos.

\section{Suspension culture establishment from embryogenic callus}

The embryogenic cell suspension was established by incubating a 4- to 5-week-old friable embryogenic callus in MS liquid medium containing the same level of PGRs - that is, $1 \mathrm{mg} / 12,4$-D and $0.2 \mathrm{mg} / 1 \mathrm{BA}$. The conical flasks were kept on a rotary shaker $(80 \mathrm{rpm})$ and incubated in a culture room at $25 \pm 2{ }^{\circ} \mathrm{C}$ under a 16-hour light period that was generated by cool-white fluorescent lamps (100 $\left.\mathrm{mol} \mathrm{m}^{-2} \mathrm{~s}^{-1} \mathrm{PFD}\right)$.

\section{Isolation of protoplast and enzyme mixture solutions}

Protoplasts were prepared from an embryogenic suspension (4 days old; $1 \mathrm{~g}$ fresh weight). The liquid me- dium was replaced by $10 \mathrm{ml}$ enzymatic mixture and was placed in the dark overnight on a rotary shaker for gentle agitation $(50 \mathrm{rpm})$. The enzyme mixture of cellulase Onozuka R-10 (2\%), pectinase (1\%), and macerozyme R-10 (0.2\%) in combination with two osmotic systems - sorbitol and mannitol - at $0.6 \mathrm{M}$ with $5 \mathrm{mM}$ $\mathrm{CaCl}_{2} \cdot 2 \mathrm{H}_{2} \mathrm{O}$ were used separately to optimize the osmotic conditions. All enzymes were procured from Sigma-Aldrich, USA, and the enzymes were filter sterilized through a $0.45-\mu \mathrm{m}$ Millipore filter prior to use. The mixture was incubated on a rotary shaker under the same light and temperature conditionsas for obtaining protoplasts.The digested cells were filtered through a stainless steel mesh $(100 \mu \mathrm{m})$ under aseptic conditions and the filtrate was centrifuged at $100 \times \mathrm{g}$ for $10 \mathrm{minu}-$ tes. The pellet of protoplasts was washed twice with a washing solution $\left(0.6 \mathrm{M}\right.$ sorbitol, $5 \mathrm{mM} \mathrm{CaCl}{ }_{2} \cdot 2 \mathrm{H}_{2} \mathrm{O}$, $\mathrm{pH}$ 5.8) to remove all traces of the enzymatic solution. The yield of protoplasts was determined by counting the number of protoplasts using a hemocytometer, and viability was assessed by Evan's blue (0.04\%) stain according to the Wiszniewska and Piwowarczyk method (2014).

\section{Protoplast division and microcalli/calli formation}

Two levels of protoplast density, $1 \times 10^{5}$ and $2 \times 10^{5}$ protoplasts $/ \mathrm{ml}$ were used in the liquid MS amended separately with 2,4-D (0.2 and $0.5 \mathrm{mg} / \mathrm{l})$ and $0.2 \mathrm{mg} / \mathrm{l}$ BA, and NAA $(0.2$ and $0.5 \mathrm{mg} / \mathrm{l})$ and $0.2 \mathrm{mg} / 1 \mathrm{BA}$ for protoplast division. Both cell division and colony formation were monitored after the protoplast incubation; plating efficiency (PE) was calculated after 2 weeks of incubation.

The PE was calculated by using the formula:

$$
\mathrm{PE}=\frac{\text { Number of dividing colonies per field }}{\text { Number of live protoplasts at plating }} \times 100
$$

After the division of protoplasts, aliquots containing small cell aggregates were poured onto a solid MS medium supplemented with $0.5 \mathrm{mg} / 1$ 2,4-D for the formation of micro-colonies. The micro-callus/calli of the two different varieties of coriander (Co-1and RS) were later sub-cultured on MS supplemented with $0.5,1,1.5$, and $2 \mathrm{mg} / 12$,4-D separately for the differentiation of somatic embryos. The embryos were formed in variable numbers that were counted. 


\section{Somatic embryo germination and development of plantlets}

The embryos progressed well and mature somatic embryos were selected and cultured on MS medium supplemented with various concentrations of $\mathrm{BA}(0.5,1$, and $1.5 \mathrm{mg} / \mathrm{l})$ and $\mathrm{GA}_{3}(0.25$ and $5 \mathrm{mg} / \mathrm{l})$ for the development of plants. The germination frequency of embryos from two different coriander varieties (Co-1and RS) was noted and tabulated.

\section{Statistical analysis}

For callus induction, 30 cotyledon explants were inoculated in each treatment, which was replicated thrice. The data on the frequency of response and the numbers of somatic embryos induced per $0.5 \mathrm{~g}$ callus were recorded after 4 weeks of culture by using six test tubes per treatment. The protoplast isolation, culture, and all other treatments were carried out in three replicates each. Data are presented as mean and standard deviation (mean \pm SD). The significance of differences among the means was carried out using Duncan's Multiple Range Test (DMRT; Duncan, 1995) at $P=0.05$.

\section{Results}

\section{Callus induction and somatic embryogenesis}

Two coriander varieties (Co-1 and RS) were selected for this investigation, and cotyledons of in vitrogerminated seedlings were used as explants. The callus was induced profusely from cotyledons on a variety of PGRamended MS medium; herein, $0.5 \mathrm{mg} / 1$ 2,4-D showed a good frequency of callus induction in both of the tested varieties (53.6\% and 51.3\%, respectively). The callus induction frequency increased on the medium supplemented with $0.5 \mathrm{mg} / 1$ 2,4-D and $0.2 \mathrm{mg} / 1 \mathrm{BA}$, and showed a maximum frequency of $61.6 \%$ and $59.3 \%$ in the Co- 1 and RS varieties, respectively (Table 1). However, the callus induction frequency decreased with increase in 2,4-D levels. The callus was a soft and white tissue, and it appeared from the excised section of explants. The nature and color of the callus changed on the basis of PGR use, their concentrations, and incubation period. The callus grew well with a high callus biomass fresh weight (with $0.65 \mathrm{~g}$ and $0.6 \mathrm{~g}$ in Co-1 and RS, respectively) on $0.5 \mathrm{mg} / 12,4-\mathrm{D}$ and $0.2 \mathrm{mg} / \mathrm{l} \mathrm{BA}$ amended medium. Within approximately 4 weeks, the cotyledon-calli transformed into embryogenic calli, characterized by a compact granular appearance.
On this granular embryogenic callus, somatic embryos started to differentiate at variable numbers. The $1 \mathrm{mg} / 1$ 2,4-D-amended MS medium showed a maximum embryogenic induction frequency (53\%), with the highest number of embryos in Co-1 (37.7 embryos/0.5 g of callus). In RS, the embryo-forming ability was even better - exhibiting 58\% embryogenic frequency with 41.6 mean number of embryos/ culture (Table 2).

\section{Enzyme mixture and protoplast yield}

The embryogenic suspension was established from a friable embryogenic callus in $1 \mathrm{mg} / 12,4-\mathrm{D}$-and $0.2 \mathrm{mg} / 1$ BA-supplemented liquid MS medium (Fig. 1A). A 4-dayold suspension was used for the protoplast-isolation study. The effect of cellulase, pectinase, and macerozyme enzymes in two treatments with different osmotic stabilizers (sorbitol and mannitol) on the protoplast yield and viability was studied. The enzyme combination with the added mannitol $(0.6 \mathrm{M})$ osmoticum yielded good numbers of protoplasts, both in Co-1 $\left(4.84 \times 10^{6}\right)$ and RS $\left(4.60 \times 10^{6}\right)$, and had good viability (i.e. $93.8 \%$ and $90 \%$, respectively) when compared to sorbitol as an osmotic stabilizer. The viable protoplasts were round or nearly round in structure without shrinkage. The influence of osmoticum and enzyme solutions on protoplast yield and viability is shown in Table 3.

\section{Protoplast division and regeneration}

The viable protoplasts were cultured in a liquid MS medium amended with different concentrations of NAA, 2,4-D, and BA for protoplast division. Among the two protoplast densities used, we noted that a higher protoplast density $\left(2 \times 10^{5}\right.$ protoplasts $\left./ \mathrm{ml}\right)$ had greater effectiveness in producing a fast division of protoplasts (Fig. 1D), whereas a lower protoplast density $\left(1 \times 10^{5}\right.$ protoplasts $/ \mathrm{ml}$ ) yielded no response. The protoplasts divided satisfactorily in a liquid medium; supplementation with $0.2 \mathrm{mg} / 1$ each of NAA and BA generated a higher PE (6.2\% and 5.4\% in Co- 1 and RS, respectively) compared to the $0.2 \mathrm{mg} / 12,4$-D- and $0.2 \mathrm{mg} / 1 \mathrm{BA}$-amended MS medium (5.5\% and 5\% in Co-1 and RS, respectively; Fig. $1 \mathrm{E}$ and Fig. 2). The protoplast-derived microcalli grew well on a solid MS medium and formed whitish yellow callus on 2,4-D-amended MS medium (Fig. 1F). Within 3-4 weeks, the protoplast-derived calli developed into an embryogenic callus that was very similar to the cotyledon-induced embryogenic callus. 
Table 1. Callus induction frequency and fresh weight of callus from cotyledon explants in Co-1 and RS; mean values within a column followed by different letters are significantly different (at $P=0.05$ ) according to DMRT; data were recorded after 4 weeks of culture

\begin{tabular}{|c|c|c|c|c|c|}
\hline \multirow{2}{*}{\multicolumn{2}{|c|}{$\begin{array}{l}\text { PGR concentrations } \\
{[\mathrm{mg} / \mathrm{l}]}\end{array}$}} & \multicolumn{2}{|c|}{ Co-1 } & \multicolumn{2}{|c|}{$\mathrm{RS}$} \\
\hline & & \multirow{2}{*}{$\begin{array}{l}\text { callus induction } \\
\text { frequency }\end{array}$} & \multirow{2}{*}{$\begin{array}{l}\text { fresh weight } \\
{[\mathrm{g}]}\end{array}$} & \multirow{2}{*}{$\begin{array}{l}\text { callus induction } \\
\text { frequency }\end{array}$} & \multirow{2}{*}{$\begin{array}{l}\text { fresh weight } \\
{[\mathrm{g}]}\end{array}$} \\
\hline $2,4-\mathrm{D}$ & $\mathrm{BA}$ & & & & \\
\hline \multirow{2}{*}{0.5} & \multirow{2}{*}{0.2} & $53.6 \pm 3.5^{\mathrm{b}}$ & $0.52 \pm 0.05^{\mathrm{b}}$ & $51.3 \pm 3.5^{\mathrm{b}}$ & $0.53 \pm 0.05^{b}$ \\
\hline & & $61.6 \pm 3.7^{\mathrm{a}}$ & $0.65 \pm 0.06^{\mathrm{a}}$ & $59.3 \pm 3.2^{\mathrm{a}}$ & $0.60 \pm 0.05^{\mathrm{a}}$ \\
\hline \multirow{2}{*}{1.0} & \multirow{2}{*}{0.2} & $40.0 \pm 3.0^{c}$ & $0.36 \pm 0.05^{\mathrm{c}}$ & $36.6 \pm 3.5^{\mathrm{d}}$ & $0.30 \pm 0.04^{\mathrm{d}}$ \\
\hline & & $43.6 \pm 4.1^{\mathrm{c}}$ & $0.40 \pm 0.04^{\mathrm{c}}$ & $40.0 \pm 3.0^{c}$ & $0.37 \pm 0.05^{\mathrm{c}}$ \\
\hline \multirow{2}{*}{1.5} & \multirow{2}{*}{0.2} & $24.4 \pm 3.0^{\mathrm{d}}$ & $0.20 \pm 0.05^{\mathrm{e}}$ & $22.6 \pm 2.5^{\mathrm{e}}$ & $0.17 \pm 0.05^{\mathrm{e}}$ \\
\hline & & $27.0 \pm 2.6^{\mathrm{d}}$ & $0.25 \pm 0.04^{\mathrm{d}}$ & $25.4 \pm 2.6^{\mathrm{e}}$ & $0.20 \pm 0.04^{\mathrm{e}}$ \\
\hline \multirow{2}{*}{2.0} & \multirow{2}{*}{0.2} & $18.0 \pm 2.0^{\mathrm{e}}$ & $0.14 \pm 0.05^{g}$ & $14.0 \pm 1.5^{\mathrm{g}}$ & $0.12 \pm 0.06^{\mathrm{f}}$ \\
\hline & & $19.4 \pm 2.5^{\mathrm{e}}$ & $0.18 \pm 0.06^{\mathrm{f}}$ & $18.6 \pm 2.5^{\mathrm{f}}$ & $0.14 \pm 0.04^{\mathrm{f}}$ \\
\hline
\end{tabular}

Table 2. Somatic embryogenic induction frequency and numbers of embryos formed per $500 \mathrm{mg}$ embryogenic callus in Co-1 and RS; mean values within a column followed by different letters are significantly different (at $P=0.05$ ) according DMRT; data were recorded after 4 weeks of culture

\begin{tabular}{c|c|c|c|c}
\hline \multirow{2}{*}{$\begin{array}{c}2,4-\mathrm{D} \\
{[\mathrm{mg} / \mathrm{l}]}\end{array}$} & $\begin{array}{c}\text { Co-1 } \\
\text { embryogenic } \\
\text { induction } \\
\text { frequency }\end{array}$ & $\begin{array}{c}\text { number } \\
\text { of SE/500 mg } \\
\text { callus mass }\end{array}$ & $\begin{array}{c}\text { embryogenic } \\
\text { induction } \\
\text { frequency }\end{array}$ & $\begin{array}{c}\text { number } \\
\text { of SE/500 mg } \\
\text { callus mass }\end{array}$ \\
\hline 0.5 & $41.0 \pm 3.3^{\mathrm{c}}$ & $25.6 \pm 3.5^{\mathrm{b}}$ & $42.6 \pm 2.3^{\mathrm{c}}$ & $26.0 \pm 3.0^{\mathrm{c}}$ \\
\hline 1.0 & $53.0 \pm 3.7^{\mathrm{a}}$ & $37.7 \pm 4.2^{\mathrm{a}}$ & $58.0 \pm 3.4^{\mathrm{a}}$ & $41.6 \pm 3.2^{\mathrm{a}}$ \\
\hline 1.5 & $48.0 \pm 2.6^{\mathrm{b}}$ & $28.3 \pm 4.0^{\mathrm{b}}$ & $47.3 \pm 2.5^{\mathrm{b}}$ & $34.3 \pm 3.0^{\mathrm{b}}$ \\
\hline 2.0 & $31.3 \pm 2.2^{\mathrm{d}}$ & $20.0 \pm 3.2^{\mathrm{c}}$ & $35.0 \pm 2.2^{\mathrm{d}}$ & $22.7 \pm 2.6^{\mathrm{d}}$ \\
\hline
\end{tabular}

\section{Somatic embryo induction from protoplast-callus}

Similarly as did the cotyledonary embryogenic callus, the protoplast callus started to differentiate a variable number of somatic embryos within 4 weeks of incubation. The $1 \mathrm{mg} / 1$ 2,4-D-amended MS medium was noted to be very productive and induced more embryos (i.e. 47 embryos/culture in Co-1 and 53.5 embryos/culture in RS; Fig. 3).The embryos originated at the upper surface of the callus and were non-synchronous. Various embryos at different stages of development are shown in Figure $1 \mathrm{G}$ and Figure $1 \mathrm{H}$. The cotyledonary embryos were green and were isolated and placed on media with other PGR combinations and concentrations for obtaining plants, because the development of somatic embryos was slow in the 2,4-D-amended medium and was limited to the early embryo stage.
The well-developed cotyledonary somatic embryos were later transferred to the $\mathrm{BA}$ - and $\mathrm{GA}_{3}$-amended medium for embryo germination. In these media treatments, the embryos produced green leafy shoots (Fig. 1I) and maximal regeneration was noted in the $1 \mathrm{mg} / \mathrm{l} \mathrm{BA}$ and $0.5 \mathrm{mg} / \mathrm{lGA}_{3}$-supplemented medium - with a regeneration frequency of $81.0 \%$ and $88.7 \%$ in $\mathrm{Co}-1$ and $\mathrm{RS}$, respectively. Furthermore, other $\mathrm{BA}$ and $\mathrm{GA}_{3}$ levels were noted to be very efficient in producing plantlets from embryos. The effects of BA and $\mathrm{GA}_{3}$ treatments are summarized in Table 4. The protoplast-regenerated plants were morphologically similar to the parent stock; no apparent phenotypic alteration was noted. The whole protocol took approximately 4-5 months to obtain plants that grew naturally in outdoor conditions. 

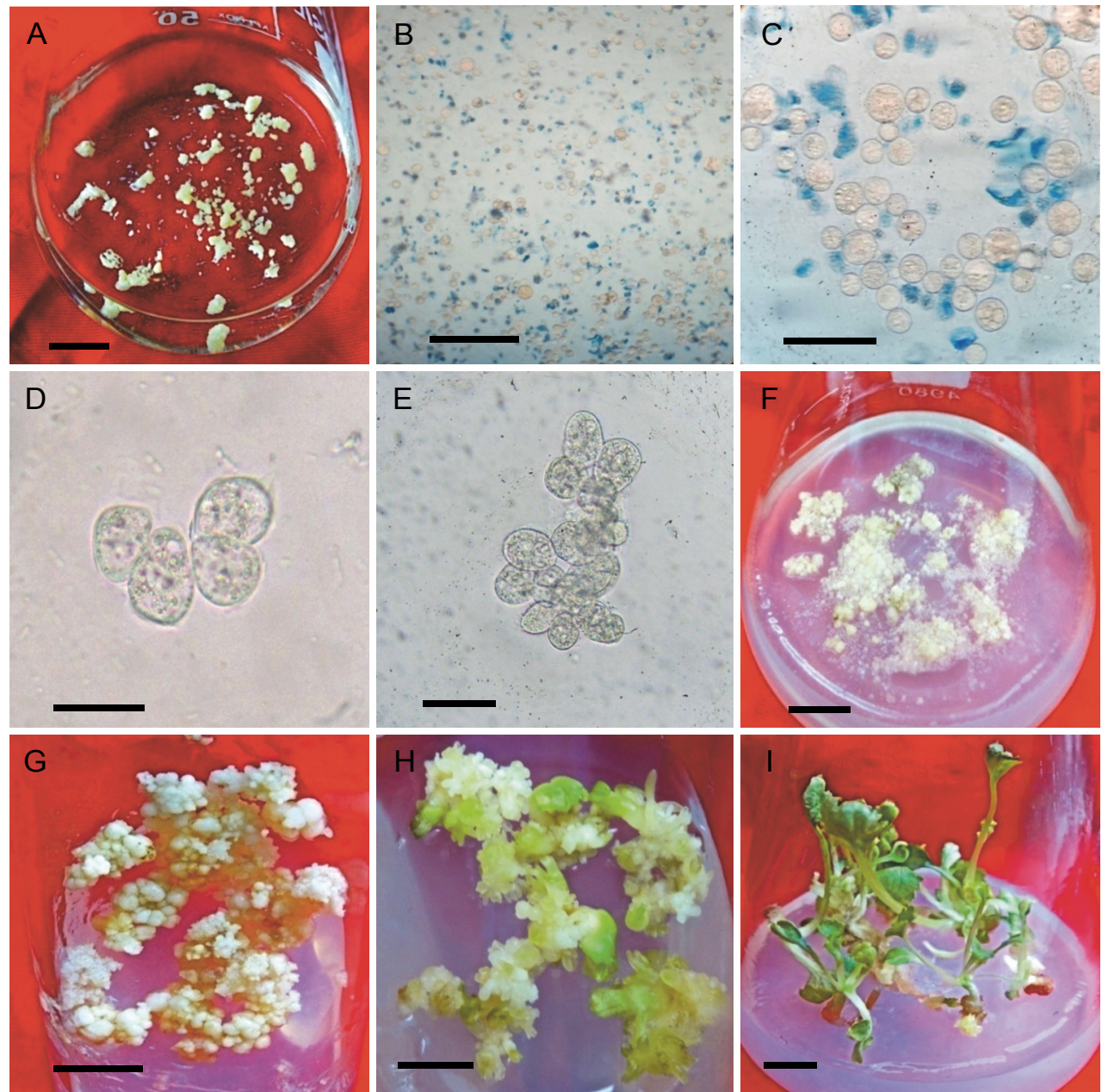

Fig. 1. Protoplast isolation and regeneration in Co-1; A) suspension culture; B) protoplasts under $10 \times$ magnification; C) protoplasts under $40 \times$ magnification; D) protoplast-derived cell division; E) protoplast-derived micro-colony; F) callus formation; $\mathrm{G}$ ) somatic embryos at induction stage; $\mathrm{H}$ ) mature somatic embryos; I) plantlet formation (bars $\mathrm{A}=1 \mathrm{~cm} ; \mathrm{B}$ and $\mathrm{C}=100 \mu \mathrm{m}$; $\mathrm{D}$ and $\mathrm{E}=50 \mu \mathrm{m} ;$ and $\mathrm{F}-\mathrm{I}=1 \mathrm{~cm})$

Table 3. Effect of mannitol and sorbitol osmoticum on the protoplast yield and viability with an enzyme mixture of cellulase $(2 \%)+$ pectinase $(1 \%)+$ macerozyme $(0.2 \%)$; mean values in the column followed by different letters are significantly different (at $P=0.05$ ) according to DMRT

\begin{tabular}{c|c|c|c|c}
\hline \multirow{2}{*}{$\begin{array}{c}\text { Osmotica }(0.6 \mathrm{M}) \\
+5 \mathrm{Mm} \mathrm{CaCl}_{2} \cdot 2 \mathrm{H}_{2} 0\end{array}$} & \multicolumn{2}{|c|}{ Protoplast yield $\left(\times 10^{6}\right)$} & \multicolumn{2}{c}{ Protoplast viability [\%] } \\
\cline { 2 - 5 } & $\mathrm{Co}-1$ & $\mathrm{RS}$ & $\mathrm{Co}-1$ & $\mathrm{RS}$ \\
\hline Mannitol & $4.84 \pm 1.6^{\mathrm{a}}$ & $4.60 \pm 1.5^{\mathrm{a}}$ & $93.8 \pm 3.2^{\mathrm{a}}$ & $92.0 \pm 2.0^{\mathrm{a}}$ \\
\hline Sorbitol & $4.30 \pm 1.15^{\mathrm{b}}$ & $4.1 \pm 1.2^{\mathrm{b}}$ & $87.2 \pm 2.8^{\mathrm{b}}$ & $83.4 \pm 2.5^{\mathrm{b}}$ \\
\hline
\end{tabular}

\section{Discussion}

In this study, we developed an efficient protoplast isolation, culture, and plant regeneration protocol via somatic embryogenesis in two coriander varieties. We used the embryogenic cell suspension as a source of protoplast, similarly as in other studies (Guo et al., 2007; Mehpara et al., 2012). Cell suspensions have been reported widely to be a good source material for the successful isolation of protoplasts in several of the investigated plant genera (Masani et al., 2013). In order to 


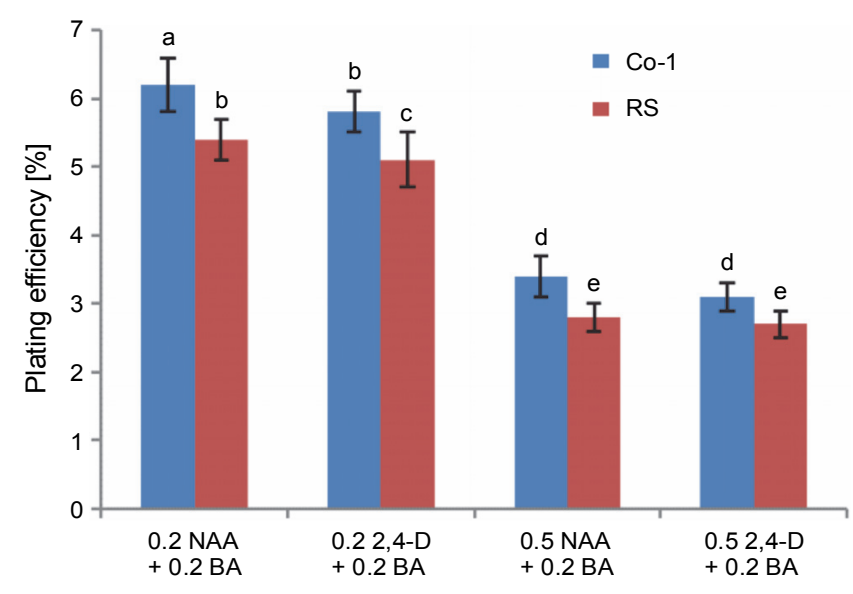

Fig. 2. PE of the Co-1- and RS-derived protoplasts, cultured at different concentrations of NAA, 2,4-D, and BA, seen after 2 -week incubation of protoplasts at a density of $2 \times 10^{5} / \mathrm{ml}$; mean values followed by different letters are significantly different (at $P=0.05$ ) according to DMRT

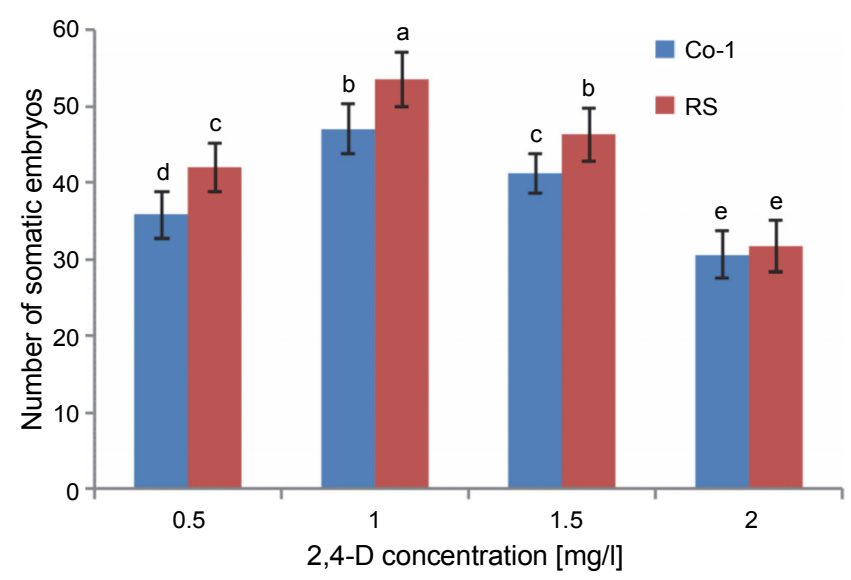

Fig. 3. Number of somatic embryos formed per $500 \mathrm{mg}$ protoplast generated embryogenic callus in $\mathrm{Co}-1$ and RS; mean values followed by different letters are significantly different (at $P=0.05$ ) according to DMRT

sustain the structure and function of protoplasts, protoplasts are released from cells through treatment with cell wall-degrading enzyme solutions and osmotic stabilizers (Zhang et al., 2011).The use of cell wall-degradation enzymes have made it possible to isolate viable protoplasts in large numbers for experimental purposes (Duquenne et al., 2007). In our study, overnight incubation in enzyme solution was found to be optimal for the isolation of viable protoplasts. Because protoplasts are fragile and sensitive to enzyme digestion, prolonged incubation in the enzyme solution leads to protoplast breakage and dysfunction although the yield is often high
Table 4. Somatic embryo germination in Co-1 and RS at different concentrations of BA- and $\mathrm{GA}_{3}$-supplemented MS medium. Mean values in the column followed by different letters are significantly different (at $P=0.05$ ) according to DMRT

\begin{tabular}{c|c|c|c}
\hline \multicolumn{2}{c|}{$\begin{array}{c}\text { PGR concentrations } \\
{[\mathrm{mg} / \mathrm{l}]}\end{array}$} & \multicolumn{2}{c}{ Germination frequency } \\
\hline BA & $\mathrm{GA}_{3}$ & Co-1 & RS \\
\hline 0.5 & 0.25 & $56.8 \pm 3.4^{\mathrm{c}}$ & $62.2 \pm 3.3^{\mathrm{c}}$ \\
\hline 1.0 & 0.25 & $72.5 \pm 4.7^{\mathrm{b}}$ & $76.0 \pm 4.0^{\mathrm{b}}$ \\
\hline 1.0 & 0.5 & $81.0 \pm 4.6^{\mathrm{a}}$ & $88.7 \pm 5.4^{\mathrm{a}}$ \\
\hline 1.5 & 0.5 & $57.3 \pm 2.5^{\mathrm{c}}$ & $65.5 \pm 3.5^{\mathrm{b}}$ \\
\hline
\end{tabular}

(Tudses et al., 2014). Navratilova and coworkers (2000) observed that the culture-induced damage could be minimized by modifying enzyme treatments or reducing the exposure time to enzyme solution. Moreover, Chamani and coworkers (2012) noted that appropriate enzyme treatment and incubation time are crucial for obtaining viable protoplasts when working on diverse tissues of different plant species. In a conventional optimization process, one parameter is altered at a time, keeping the other variables constant; this enables assessment of the performance of a specific treatment (Zhang et al., 2011). In this investigation, we noted that $2 \%$ cellulose Onozuka $\mathrm{R}-10,1 \%$ pectinase, and $0.2 \%$ macerozyme $\mathrm{R}-10$ were the most appropriate enzyme concentrations, with mannitol as the osmoticum for the highest yield and viability that was obtained for the coriander protoplasts. The same enzyme combination treatment was proved to be efficient for the production of the maximum yield of protoplasts in several plant genera that were investigated (Mehpara et al., 2012). Rastogi (2003) reported that an elevated hydrolytic enzyme level enhanced the number of protoplasts by facilitating the formation of a higher number of enzyme-substrate complexes. A higher enzyme level was noted to negatively influence the protoplast yield and viability because the pectinase and cellulase enzymes over-digest protoplasts (Raiker et al., 2008). The osmotic conditions of the media are critically important, and several osmotic compounds such as mannitol, sorbitol, glucose, or sucrose are frequently added to the enzyme mixtures and noted to be very effective in a number of studies (Navratilova, 2004). In the present study, the use of $0.6 \mathrm{M}$ mannitol showed the highest viability $(85.84 \%)$ - significantly higher than with the use of $0.6 \mathrm{M}$ sorbitol. As mannitol had a better influence, 
this osmotic element was identified as an ideal osmotic treatment for achieving the maximum yield and viable protoplasts in coriander. In general, protoplasts are more stable in a slightly hypotonic environment as compared to the isotonic solution, and appropriate osmotic bathing has been noted to prevent protoplasts from bursting and shrinking (Duquenne et al., 2007; Zhang et al., 2011).

The efficiency of protoplast isolation and regeneration depends on many factors, including the genotype, inoculation density, culture system, and medium composition (Prange et al., 2010; Tiwari et al., 2010). Protoplasts were cultured in a liquid MS medium at a density of $1 \times 10^{5}$ and $2 \times 10^{5}$ protoplasts $\mathrm{m} / \mathrm{l}$, and the division of protoplasts took place at the optimal density of $2 \times 10^{5}$ protoplasts $\mathrm{m} / 1$. With this density, cell colonies were produced from individual protoplasts that grew steadily in the culture. Therefore, the density of protoplasts is important because it influences the initiation of cell division, as reported earlier (Hahne et al., 1990). Davey and coworkers (2000) observed that mitotic divisions and a rapid cell wall synthesis in the early phases of culture are crucial in the successful development of "protoplast-to-plant" recovery systems. Furthermore, the plating density of protoplasts has an important role in potential cell division and the subsequent colony formation (Davey et al., 2005). The nutritional components used in most culture media are insufficient to induce divisions in protoplasts plated at a lower density. In this study, the division of protoplast was high in a liquid medium, similar to that reported in several other studies (Tahami et al., 2014), where the division of protoplasts was noted to be more vigorous in a liquid medium. In a solid medium, the toxic compounds released from dying neighboring protoplasts may accumulate and inhibit the division of other living protoplasts; moreover, in a liquid medium, the accumulation of these toxic compounds may be prevented or diluted (Duquenne et al., 2007).

Davey and coworkers (2005) reported that PGRs, such as auxins and cytokinins play a central role in efficient protoplast division; however, the concentrations and combinations need optimization at each step of protoplast development. In our study, various PGRs such as 2,4-D, NAA, and BA were tested, of which the combinations of 2,4-D and BA at a high concentration influenced protoplast division, which is consistent with earlier observations noted in Allium cepa (Karim and
Adachi, 1997; Pongchawee et al., 2006). In the present study, the cell division, cell wall regeneration, and callus formation were efficiently accomplished in the PGR-supplemented medium. The other PGRs, such as BA with NAA, increased the PE; this observation is in agreement with the earlier study of Assani and coworkers (2001). Auxins are particularly involved in cell division and callus formation, and these compounds play an important role in the acquisition of embryos (Zhang et al., 2010; Devi and Narmathabai, 2011; Palmer and Keller, 2011; Ma et al., 2011). The persistence of 2,4-D, however, blocks embryo development and, therefore, a transfer of embryos to other PGR treatments has been suggested for its further development (Junaid et al., 2006). Vookova and coworkers (2010)reported that the selection of PGRs and their concentrations are essential in the optimization of a maturation medium. Following maturation, a successful and fast germination of somatic embryos is another crucial step in obtaining plantlets (Devi and Narmathabai, 2011). In our study, mature somatic embryos germinated fast in a $\mathrm{GA}_{3}$ and $\mathrm{BA}$ amended MS medium, similarly to that in other studies (Ali et al., 2010). Nakano and coworkers (2005) reported the enhanced conversion of plantlets from somatic embryos at a lower BA concentration. Furthermore, additional changes in the germination medium increased the germination frequency of somatic embryos, which matured under suboptimal conditions (Stasolla and Yeung, 2003). The induction of somatic embryos on a protoplastderived callus has previously been reported in several studies (Tomiczak et al., 2015). In addition, plants were regenerated from a protoplast-callus by following the organogenic pathway in other studies (Rezazadeh and Niedz, 2015). In embryo-obtained plants, the differentiation of shoot- and root-apical meristem is unique and is often true-to type (Stasolla and Yeung, 2003). Here, the embryo-regenerated plants were morphologically similar to parent plants. The established protoplast-isolation protocol of the two varieties could be very efficient for obtaining somatic hybrids in coriander.

\section{Conclusions}

An efficient protoplast-isolation protocol has been developed from an embryogenic suspension in two coriander varieties that reproducibly showed plant regeneration. The yield and viability of protoplasts was highest in 
the cellulase Onozuka R-10 (2\%), pectinase (1\%), and macerozyme R-10 (0.2\%)-treated combinations. The use of $0.6 \mathrm{M}$ mannitol as osmoticum resulted in a good yield and viability of the protoplast. The successful isolation of protoplast and plant regeneration are key steps in somatic hybridization. The fast protoplast-isolation and plant regeneration method we established in Co-1 and RS may offer a future fusion possibility of transferring important genetic traits. The protocol developed in this study may be employed in closely and widely related coriander genotypes.

\section{Conflict of interests}

The authors declare they have no conflict of interests.

\section{References}

Ali S.B.G.M., Kourosh V., Hassan B.S., Siamak K., Charles L. (2010) Enhancement of maturation and germination of somatic embryos in Persian walnut (Juglans regia 1.) using osmolites, hormones and cold treatments. Afr. J. Food Sci. 4(12): 735-743.

Assani A., Haicour R., Wenzel G., Cote F., Bakry F., ForoughiWehr B., Ducreux G., Aguillar M.E., Grapin A. (2001) Plant regeneration from protoplasts of dessert banana $\mathrm{CV}$. Grande Naine (Musa spp., Cavendish Sub-group AAA) via somatic embryogenesis. Plant Cell Rep. 20: 482-488.

Chamani E., Tahami S.K., Zare N., Zakaria R.A., Mohebodini M., Joyce D. (2012) Effect of different cellulase and pectinase enzyme treatments on protoplast isolation and viability in Lilium ledebeourii Bioss. Not. Bot. Horti. Agrobo. 40(2): 123-128.

Ciju J.R. (2015) Cilantro, the coriander greens. Growing practices and nutritional information, pp. 28.

Darughe F., Barzegar M., Sahari M.A. (2012) Antioxidant and antifungal activity of Coriander (Coriandrum sativum L.) essential oil in cake. Int. Food Res. J. 19(3): 1253-1260.

Davey M.R., Anthony P., Power J.B., Lowe K.C. (2005) Plant protoplasts: status and biotechnological perspectives. Biotechnol. Adv. 23: 131-171.

Davey M.R., Power J.B., Lowe K.C. (2000) Plant protoplasts. [in:] Encyclopaedia of cell technology. Ed. Spier R.E. New York, USA, John Wiley and Sons: 1034-1042.

Devi B.C., Narmathabai V. (2011) Somatic embryogenesis in the medicinal legume Desmodium motorium (Houtt.) Merr. Plant Cell Tiss. Org. Cult. 106: 409-418.

Duarte A., Ferreira S., Silva F., Domingues F.C. (2012) Synergistic activity of coriander oil and conventional antibiotics against Acinetobacte rbaumannii. Phytomedicine 19: $236-238$.

Duncan D.B.(1955) Multiple range and multiple $F$ tests. Biometrics 11: 1-42.

Duquenne B., Eeckhaut T., Werbrouck S., Huylenbroeck J.V. (2007) Effect of enzyme concentrations on protoplast iso- lation and protoplast culture of Spathiphyllum and Anthurium. Plant Cell Tiss. Org. Cult. 91: 165-173.

Eeckhaut T., Van Huylenbroeck J. (2011) Development of an optimal culture system for callogenesis of Chrysanthemum indicum protoplasts. Acta Physiol. Plant. 33: 1547-1551.

Eeckhaut T., Van Laere K., De Riek J., Van Huylenbroeck J. (2006) Overcoming interspecific barriers in ornamental plant breeding. [in:] Floriculture, ornamental and plant biotechnology: advances and topical issues. Ed. Teixeira da Silva J. London, UK, Global Science Books: 540-551.

Eidi M., Eidi A., Saeidi A., Molanaei S., Sadeghipour A., Bahar M., Bahar K. (2009) Effect of coriander seed (Coriandrum sativum L.) ethanol extract on insulin release from pancreatic beta cells in streptozotocin-induced diabetic rats. Phytother. Res. 23(3): 404-406.

Faraco M., Sansebastiano G.P.D., Spelt K., Koes R.E., Quattrocchio F.M. (2011) One protoplast is not the other. Plant Physiol. 156(2): 474-478.

Farooq M., Hegde R.V., Imamsaheb S.J. (2017) Evaluation of different of coriander genotypes for quality traits. Plant Arch. 17: 237-240.

Gao D.Y., Vallejo V.A., He B., Gai Y.C., Sun L.H. (2009) Detection of DNA changes in somaclonal mutants of rice using SSR markers and transposon display. Plant Cell Tiss. Org. Cult. 98: 187-196.

Gosal S.S., Wani S.A., Kang M.S. (2010) Biotechnology and crop improvement. J. Crop Improv. 24: 153-217.

Grafi G. (2004) How cells dedifferentiate: a lesson from plants. Dev. Biol. 268: 1-6.

Grosser J.W., Gmitter-Jr F.G. (2011) Protoplast fusion for production of tetraploids and triploids: applications for scion and rootstock breeding in citrus. Plant Cell Tiss. Org. Cult. 104: 343-357.

Grzebelus E., Szklarczyk M., Baranski R. (2012) An improved protocol for plant regeneration from leaf and hypocotylderived protoplasts of carrot. Plant Cell Tiss. Org. Cult. 109: 101-109.

Guo Y., Bai J., Zhang Z. (2007) Plant regeneration from embryogenic suspension-derived protoplasts of ginger (Zingiber officinale Rosc.). Plant Cell Tiss. Org. Cult. 89: 151-157.

Hahne B., Lorz H., Hahne G. (1990) Oat mesophyll protoplasts: Their response to various feeder cultures. Plant Cell Rep. 8: 590-593.

Horii M., Marubashi W. (2005) Even juvenile leaves of tobacco exhibit programmed cell death. Plant Biotechnol. 22: 339-344.

Jalil M., Khalid N., Othman R.Y. (2003) Plant regeneration from embryogenic suspension cultures of Musa acuminata cv. Mas (AA). Plant Cell Tiss. Org. Cult. 75: 209-214.

Junaid A., Mujib A., Bhat M.A., Sharma M.P. (2006) Somatic embryo proliferation, maturation and germination in Catharanthus roseus. Plant Cell Tiss. Org. Cult. 84: 325-332.

Karim M.A., Adachi T. (1997) Cell suspension, isolation and culture of protoplasts of Allium cepa. Plant Cell Tiss. Org. Cult. 51: 43-47. 
Kim S.W., Seung C.O., Dong S.I., Liu J.R. (2003) Plant regeneration of rose (Rosa hybrida) from embryogenic cell-derived protoplasts. Plant Cell Tiss. Org. Cult. 73: 15-19.

Larkin P.J., Scowcroft S.C. (1981) Somaclonal variation - a novel source of variability from cell culture for plant improvement. Theor. Appl. Genet. 60: 197-214.

Ma G., Lu J., da Silva J.A.T., Zhang X., Zhao J. (2011) Shoot organogenesis and somatic embryogenesis from leaf and shoot explants of Ochna integerrima (Lour). Plant Cell Tiss. Org. Cult. 104: 157-162.

Malhotra S.K., Vashishtha B.B. (2008) Coriander. [in:] Organic Spices. Ed. Parthasarathy V.A., Kandiannan K., Srinivasan V. New Delhi, New India Publishing Agency: 523-546.

Masani M.Y.A., Noll G., Parveez G.K.A., Sambanthamurthia R., Prufer D. (2013) Regeneration of viable oil palm plants from protoplasts by optimizing media components, growth regulators and cultivation procedures. Plant Sci. 210: $118-127$.

Mehpara M., Mujib A., Dipti T., Abdin M.Z. (2012) Protoplast isolation, culture and plant regeneration in Catharanthus roseus (L.) G. Don via somatic embryogenesis. Current Biotech. 1(3): 217-222.

Mujib A., Tonk D., Ali M. (2014) Plant regeneration from protoplasts in Indian local Coriandrum sativum L.: scanning electron microscopy and histological evidences for somatic embryogenesis. Plant Cell Tiss. Org. Cult. 117: 323-334.

Murashige T., Skoog F. (1962) A revised medium for rapid growth and bioassays with tobacco tissue culture. Physiol. Plant. 15: 473-497.

Nakano M., Tanaka S., Kagami S., Saito H. (2005) Plantlet regeneration from protoplasts of Muscari armeniacum Leichtl. Ex Bak. Plant Biotechnol. 22(3): 249-251.

Navratilova B. (2004) Protoplast cultures and protoplast fusion focused on Brassicaceae. Hort. Sci. (Prague) 31: 140-157.

Navratilova B., Rokytova L., Lebeda A. (2000) Isolation of mesophyll protoplasts of Cucumis spp. and Cucurbita spp. Acta Hort. 510: 425-431.

Ondrej V., Kitner M., Dolezalova I., Nadvornık P., Navratilova B., Lebeda A. (2009) Chromatin structural rearrangement during dedifferentiation of protoplasts of Cucumis sativus L. Mol. Cells 27: 443-447.

Palmer C.D., Keller W.A. (2011) Somatic embryogenesis in Crambe abyssinica Hochst. ex R.E. Fries using seedling explants. Plant Cell Tiss. Org. Cult. 104: 91-100.

Pongchawee K., Na-Nakorn U., Lamseejan S., Poompuang S., Phansiri S. (2006) Factors affecting protoplast isolation and culture of Annabias nana Engler. Int. J. Bot. 2(2): 193-200.

Prange A.N.S., Serek M., Bartsch M., Winkelmann T. (2010) Efficient and stable regeneration from protoplasts of $C y$ clamen coum Miller via somatic embryogenesis. Plant Cell Tiss. Org. Cult. 101(2): 171-182.

Rastogi S.C. (2003)Cell and Molecular Biology. United Sates of America: New Age International.
Rezazadeh R., Niedz R.P.(2015) Protoplast isolation and plant regeneration of guava (Psidium guajava L.) using experiments in mixture-amount design. Plant Cell Tiss. Org. Cult. 122: 585-604.

Rizkalla A.A., Badr-Elden A.M., Nower A.A. (2007) Protoplast isolation, salt stress and callus formation of two date palm genotypes. J. Appl. Sci. Res. 3: 1186-1194.

Samojlik I., Lakic N., Mimica-Dukic N., Dakovic-Svajcer K., Bozin B. (2010) Antioxidant and hepatoprotective potential of essential oils of coriander (Coriandrum sativum L.) and caraway (Carum carvi L.) (Apiaceae). J. Agric. Food Chem. 58(15): 8848-8853.

Shrestha B.R., Tokuhara K., Mii M. (2007) Plant regeneration from cell suspension-derived protoplasts of Phalaenopsis. Plant Cell Rep. 26:719-725.

Silva F., Ferreira S., Duarte A., Mendonca D.I., Domingues F.C. (2011) Antifungal activity of Coriandrum sativum L. essential oil, its mode of action against Candida species and potential synergism with amphotericin B. Phytomedicine 19: 42-47.

Singh A.K. (2006) Evaluation of fungicides for the control of powdery mildew disease in coriander (Coriandrum sativum L.). J. Spices Arom. Crops 15(2): 123-124.

Singh M., Chaturvedi R. (2013) Somatic Embryogenesis in Neem (Azadirachta indica A. Juss.): Current status and biotechnological perspectives. [in:] Somatic embryogenesis and gene expression. Ed. Aslam J., Srivastava P.S., Sharma M.P. New Delhi, Narosa Publishing House: 35-55.

Stasolla C., Yeung E.C. (2003) Recent advances in conifer somatic embryogenesis: improving somatic embryo quality. Plant Cell Tiss. Org. Cult. 74(1): 15-35.

Tahami S.K., Chamani E., Zare N. (2014) Plant regeneration from protoplasts of Lilium ledebourii(Baker) Boiss. J. Agricul. Sci. Tech. 16: 1133-1144.

Tiwari J.K., Sarkar D., Pandey S.K., Gopal J., Kumar. S.R. (2010) Molecular and morphological characterization of somatic hybrids between Solanum tuberosum L. and S. etuberosum Lindl. Plant Cell Tiss. Org. Cult. 103(2): 175-187.

Tomiczak K., Mikuła A., Sliwinska E., Rybczyński J.J. (2015) Autotetraploid plant regeneration by indirect somatic embryogenesis from leaf mesophyll protoplasts of diploid Gentiana decumbens L. f. In Vitro Cell Dev. Biol. Plant 51(3): 350-359.

Tudses N., Premjet S., Premjet D. (2014) Optimal conditions for high-yield protoplast isolations of Jatropa hacurcas $L$. and Ricinus communis L. Amer.-Eurasian J. Agr. Environ. Sci. 14(3): 221-230.

Vookova B., Machava J.S., Algovicova A., Kormutak A. (2010) Optimization of Algerian fir somatic embryos maturation. Biol Plant 54(1): 177-180.

Wiszniewska A., Piwowarczyk B. (2014) Studies on cell wall regeneration in protoplast culture of legumes - the effect of organic medium additives on cell wall components. Czech J. Genet. Plant Breed. 50(2): 84-91.

Xiao L., Zhang L., Yang G., Zhu H., He Y. (2012) Transcriptome of protoplasts reprogrammed into stem cells in Physcomitrella patens. PLoS ONE 7: e35961. 
Yang X., Guo X., Zhang X., Nie Y., Jin S. (2007) Plant regeneration from Gossypium davidsonii protoplasts via somatic embryogenesis. Biol. Plant. 51: 533-537.

Zhang J., Shen W., Yan P., Li X., Zhou P. (2011) Factors that influence the yield and viability of protoplasts from Carica papaya L. Afr. J. Biotechnol. 10(26): 5137-5142.
Zhang N., Fang W., Shi Y., Liu Q., Yang H., Gui R., Lin X. (2010) Somatic embryogenesis and organogenesis in Dendrocalamu shamiltonii. Plant Cell Tiss. Org. Cult. 103: 325-332. 